\title{
Effect of Grains of Paradise (GP) Extract Intake on Obesity and Sympathetic Nerve Activity
}

\author{
Hiroyuki Hattori' ${ }^{1}$, Kosei Yamauchi ${ }^{2}$, Siaw Onwona-Agyeman ${ }^{3}$, Tohru Mitsunaga ${ }^{{ }^{*}}$ \\ ${ }^{1}$ Faculty of Applied Biological Science, Gifu University, Gifu, Japan \\ ${ }^{2}$ Department of Medical Physiology, Texas A\&M Health Science Center College of Medicine, Temple, TX, USA \\ ${ }^{3}$ Institute of Agriculture, Tokyo University of Agriculture and Technology, Tokyo, Japan \\ Email: *mitunaga@gifu-u.ac.jp
}

How to cite this paper: Hattori, H., Yamauchi, K., Onwona-Agyeman, S. and Mitsunaga, T. (2017) Effect of Grains of Paradise (GP) Extract Intake on Obesity and Sympathetic Nerve Activity. American Journal of Plant Sciences, 8, 85-95.

http://dx.doi.org/10.4236/ajps.2017.82007

Received: December 7, 2016

Accepted: January 16, 2017

Published: January 19, 2017

Copyright (C) 2017 by authors and Scientific Research Publishing Inc. This work is licensed under the Creative Commons Attribution International License (CC BY 4.0).

http://creativecommons.org/licenses/by/4.0/

\begin{abstract}
The methanol extract of grains of paradise (GP), the seed of Aframomum melegueta, which is distributed throughout West Africa, was administered during an animal breeding test. The extract suppressed body weight gain and decreased the weight of adipose tissues in breeding mice, with a greater effect on mice fed a high-fat diet (HFD) than on those fed a normal diet (ND). Other significant effects of GP intake included increased serum triglyceride (TG) concentration and reduced hepatic total cholesterol (TC) and TG concentrations. GP intake markedly prevented fat accumulation and improved hepatic lipid metabolism in HFD-fed mice. In addition, GP extract at a dosage of 5 $\mathrm{mg} / \mathrm{kg}$ body weight decreased sympathetic nerve activity (SNA) in brown adipose tissue (BAT), while capsaicin, a major component of chili pepper, activated BAT SNA. This suggested that GP exerts a potential anti-obesity effect by a different mechanism from that of capsaicin.
\end{abstract}

\section{Keywords}

Anti-Obesity Effect, Grains of Paradise, Aframomum melegueta, Vanilloid, BAT SNA

\section{Introduction}

Obesity is defined as an abnormal or excessive fat accumulation and is recognized as a major risk factor for diabetes, cardiovascular disease, and cancer by the World Health Organization (WHO). The number of obese people increased more than two times between 1980 and 2014. Reducing lipid accumulation causing body weight loss is crucial to management of obesity. The development of effective treatments for overweight and obese patients has become very desirable in recent years. 
Adipose tissue is a major metabolic organ, and roughly divided into two types: one is white adipose tissue (WAT) that stores energy in the form of triglyceride; the other is brown adipose tissue (BAT). BAT is involved in the dissipation and expenditure of energy as heat. This process of thermogenesis is induced by highfat diets and cold exposure [1] [2]. Therefore, adipocytes play a key role in energy homeostasis. Activating BAT by stimulating sympathetic nerve activity (SNA) is one of the principal strategies to enhance energy expenditure and lipolysis [3] [4] [5]. This is an effective and practical approach to treating obesity-related diseases.

Aframomum melegueta is an herbaceous plant, widely distributed throughout Nigeria, Ghana, Guinea, and other countries in West Africa [6]. Its seeds are called grains of paradise (GP), Guinea pepper, alligator pepper, or melegueta pepper. It has been traditionally used as a spice for flavouring food and as a remedy for digestive and intestinal health, dysentery, migraine, and fever [7]. Recently, a number of studies have reported that GP extract has a range of activities such as antibacterial, repellent [8] [9], antioxidant, anti-inflammatory [10] [11], and hypoglycemic [12] effects. Moreover, GP contains many non-volatile pungent compounds such as 6-paradol, 6-gingerol, and 6-shogaol [13]. These compounds possess a vanillyl moiety, and are structurally similar to capsaicin and capsiate, which are found in chili pepper [14]. It is well known that capsinoids, including capsaicin and capsiate, exert an anti-obesity effect by stimulating SNA and hence BAT thermogenesis [15]. Similarly, it might be expected that GP extract containing vanilloids would activate BAT SNA and BAT thermogenesis. In the present study, GP extract was administered during an animal breeding test to investigate its efficacy in obesity prevention. Furthermore, electrical activity in BAT interscapular nerves was recorded using an electrophysiological method to investigate the anti-obesity mechanism of GP.

\section{Materials and Methods}

\subsection{General Experimental Procedures}

Tween 80 was purchased from MP Biomedicals, LLC (Santa Ana, CA, USA). Saline was purchased from Otsuka Pharmaceutical Co., Ltd. (Tokyo, Japan). A Bioelectric Amplifier ER-1 (Bio Research Center Co., Ltd., Nag) was used for amplifying and filtering sympathetic efferent nerve impulses. A PowerLab (AD Instruments Japan Inc., Nagoya, Japan) was used for converting the amplified signals, which were then recorded on a computer using Chart 5 software (AD Instruments Japan Inc.). Other commercially available products, including urethane for anesthesia, were purchased from Wako Chemicals (Richmond, VA, USA).

\subsection{Sample Preparation}

GP was provided by Share Trade Inc (Tokyo, Japan). Dried GP seed powder (about $5 \mathrm{~kg}$ ) underwent methanol extraction all night at room temperature $\left(20^{\circ} \mathrm{C} \pm 2{ }^{\circ} \mathrm{C}\right)$ and the extract was obtained in $5.6 \%$ yield based on the powder. 
The extract was dissolved in $10 \%$ Tween 80 saline solution containing $10 \%$ ethanol, and was used for oral administration during neural recording [16] [17].

\subsection{Animal Breeding}

Five-week-old male mice $(24.8 \pm 0.9 \mathrm{~g})$ were purchased from Japan SLC Inc. (Hamamatsu, Japan) and placed in a breeding environment $\left(25^{\circ} \mathrm{C} \pm 1^{\circ} \mathrm{C}, 12 \mathrm{~h}\right.$ light-dark cycle). The mice were fed a normal diet (ND) for a period of one week. Both feed and water were available ad libitum. After preliminary breeding, they were divided into five groups. Three of the groups were fed a high-fat diet (HFD),composed of ND, 20\% lard, 1\% cholesterol powder, and $0.25 \%$ sodium cholate, containing either $2 \%$ GP seed powder, $0.3 \%$ GP extract, or $1 \%$ GP extract [18]. Two control groups were fed either an ND or HFD only. At 11 weeks of age, the mice were dissected to obtain samples of serum, the liver, and fat.

All experimental procedures were approved by the Gifu University Animal Care and Use Committee.

\subsection{Determination of Total Cholesterol (TC), Triglyceride (TG), and High-Density Lipoprotein-Cholesterol (HDL-C) Accumulation in Serum and the Liver}

Blood samples were stored at room temperature $\left(20^{\circ} \mathrm{C} \pm 2^{\circ} \mathrm{C}\right)$ for $1 \mathrm{~h}$, and then centrifuged at $3500 \mathrm{rpm}$ for $15 \mathrm{~min}$ at room temperature $\left(20^{\circ} \mathrm{C} \pm 2^{\circ} \mathrm{C}\right)$. Liver tissue (40 mg) was homogenized with $0.1 \mathrm{M}$ ethyl acetate, methanol, and chloroform (4:10:5) at $4000 \mathrm{rpm}$ for $1 \mathrm{~min}$, and the homogenates were centrifuged at $5800 \mathrm{rpm}$ for $10 \mathrm{~min}$. The TC, TG, and HDL-C analyses were performed using TC, TG, and HDL-C E-test kits, respectively (Wako Pure Chemical Industries, Ltd.).

\subsection{Neural Activity Measurement}

The electrical activity of interscapular nerves innervating BAT was recorded as previously described [19]. In brief, a rat was anesthetized using urethane solution ( $1 \mathrm{~g}$ urethane/1kg body weight), and a small incision was made above the scapula to find sympathetic nerves entering BAT. Four sympathetic nerves were isolated and separated from the connective tissues. The isolated nerves were each placed on a pair of silver electrodes $(0.3 \mathrm{~mm}$, AG 401325, Nilaco Corp., Tokyo, Japan) to detect SNA, and the electrodes were immersed in mineral oil to prevent drying and for electrical insulation. Sympathetic efferent discharges were amplified and filtered, with the amplified impulses being converted to digital signals using PowerLab, and recorded using a computer software. Spikes above a threshold voltage, set just above background levels, were counted by spike histogram. Baseline BAT SNA was recorded for at least $30 \mathrm{~min}$. Following oral administration of GP extract ( $5 \mathrm{mg} / \mathrm{kg}$ body weight) via a gastric tube, BAT SNA was recorded for every five minutes.

\subsection{Statistical Analysis}

All data were expressed as means \pm SD values. Statistical significance of differ- 
ences was evaluated using the Student's t-test. The difference was considered to be significant if $p<0.05$.

\section{Results}

\subsection{GP Intake Suppresses Body Weight Gain and Lipid Accumulation}

To investigate the anti-obesity effect of GP and GP extract, the mice were divided into five groups after preliminary breeding. Mice willingly ate the feed provided in five meals, including those in the group receiving 2\% GP. Despite this, the 2\% GP group exhibited significantly lower body weight gain over the five weeks of feeding compared with the HFD group $(p<0.01)$ (Table 1 and Figure 1). The body weight gain of the groups fed GP extract with the HFD notably decreased, to a similar level as those of the mice in the ND control group

Table 1. Food intake, body weight gain, and liver, epididymal fat, and mesenteric fat weight of mice $(n=9)$ fed a normal diet (ND), high-fat diet (HFD), HFD including $0.3 \%$ GP extract, HFD including 1\% GP extract, and HFD including 2\% GP.

\begin{tabular}{cccccc}
\hline Group & $\begin{array}{c}\text { Food intake } \\
(\mathrm{g})\end{array}$ & $\begin{array}{c}\text { Body weight } \\
(\mathrm{g})\end{array}$ & $\begin{array}{c}\text { Liver weight } \\
(\mathrm{g})\end{array}$ & $\begin{array}{c}\text { Epididymal } \\
\text { fat }(\mathrm{g})\end{array}$ & $\begin{array}{c}\text { Mesenteric } \\
\text { fat }(\mathrm{g})\end{array}$ \\
\hline ND (Normal Diet) & $198.3 \pm 21.0$ & $44.0 \pm 4.7$ & $1.89 \pm 0.23$ & $1.13 \pm 0.47$ & $0.82 \pm 0.19$ \\
HFD (High Fat Diet) & $195.3 \pm 22.2$ & $52.3 \pm 5.8^{\mathrm{c}}$ & $2.59 \pm 0.48^{\mathrm{c}}$ & $2.16 \pm 0.75^{\mathrm{c}}$ & $1.36 \pm 0.51^{\mathrm{c}}$ \\
& & & & & \\
HFD + 0.3\% GP ext. & $200.2 \pm 26.5$ & $42.1 \pm 3.2^{\mathrm{f}}$ & $2.63 \pm 0.29$ & $0.80 \pm 0.15^{\mathrm{f}}$ & $0.68 \pm 0.10^{\mathrm{d}}$ \\
& & & & & \\
HFD + 1\% GP ext. & $220.6 \pm 27.3$ & $40.6 \pm 3.1^{\mathrm{f}}$ & $2.69 \pm 0.32$ & $0.90 \pm 0.29^{\mathrm{f}}$ & $0.69 \pm 0.20^{\mathrm{d}}$ \\
HFD + 2\% GP seed & $245.8 \pm 15.6^{\mathrm{a}}$ & $42.5 \pm 4.6^{\mathrm{d}}$ & $2.63 \pm 0.53$ & $0.90 \pm 0.28^{\mathrm{f}}$ & $0.53 \pm 0.24^{\mathrm{f}}$ \\
\hline
\end{tabular}

All data were expressed as the mean \pm S.D. Differences were examined for statistical significance using Student's t-test. $\mathrm{n}=9{ }^{\mathrm{a}, \mathrm{c}}: p<0.05,0.01$ compared with ND values respectively. ${ }^{\mathrm{d}, \mathrm{f}}: p<0.01,0.001$ compared with HFD values respectively.

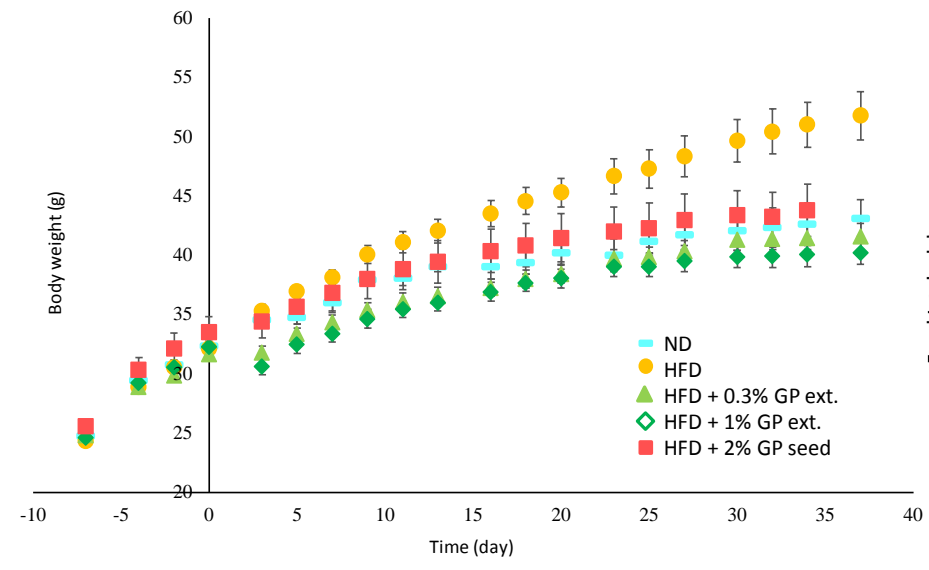

(a)

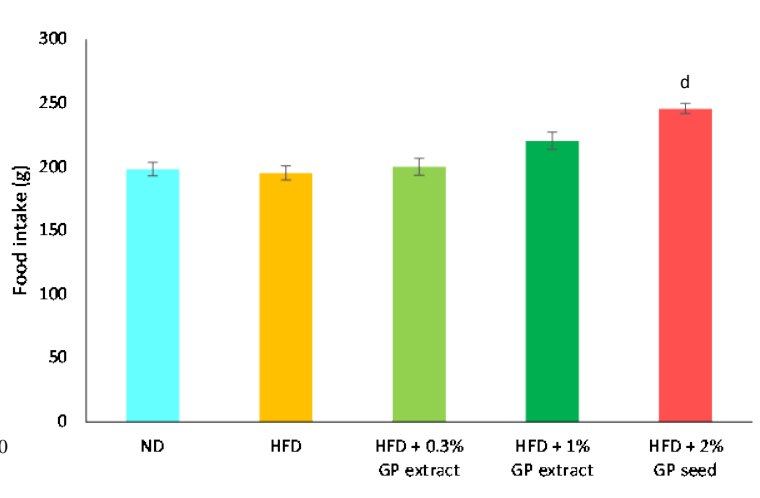

(b)

Figure 1. Body weight over time in mice $(\mathrm{n}=9)$ fed a normal diet $(\mathrm{ND})$, high-fat diet (HFD), HFD including $0.3 \%$ GP extract, HFD including 1\% GP extract, and HFD including 2\% GP (a) and the total food intake per mouse (b). d: $p<0.01$ compared with HFD values. 
(0.3\% GP extract group: $p<0.001,1 \%$ GP extract group: $p<0.001)$. Epididymal fat and mesenteric fat weights significantly decreased in the groups receiving GP in HFD when compared with those in the ND control group $0.3 \%$ GP extract group: $p<0.001$ and $<0.01$, respectively; $1 \%$ GP extract group: $p<0.001$ and $<$ 0.01 , respectively; $2 \%$ GP group: $p<0.01$ and $<0.001$, respectively).

Lipid accumulation was further investigated to explore the anti-obesity effect of GP on mice. HFD intake significantly increased the total cholesterol (TC) and triglyceride (TG) concentration in the liver. GP intake had no significant impact on liver weight (Table 2 and Figure 2). However, the GP and GP extract groups had significantly decreased levels of hepatic TC and TG. This effect was most marked in the 1\% GP extract group, whose TC and TG levels (190 and 260 $\mathrm{mg} / \mathrm{dL}$, respectively) were far lower than those of the HFD group (257 and 388 $\mathrm{mg} / \mathrm{dL}$, respectively). In contrast, there was no significant difference in serum levels of either TC or high-density lipoprotein-cholesterol (HDL-C) among any of the groups on the HFD. Serum TG concentrations significantly increased in the GP intake group (0.3\% GP extract group: $p<0.05 ; 1 \%$ GP extract group: $p<$ 0.01) (Table 2 and Figure 3).

Table 2. Total cholesterol (TC), triglyceride (TG), and high-density lipoprotein- cholesterol $(\mathrm{HDL}-\mathrm{C})$ concentrations in serum and the livers of mice $(\mathrm{n}=9)$ fed a normal diet (ND), high-fat diet (HFD), HFD including 0.3\% GP extract, HFD including 1\% GP extract, and HFD including $2 \%$ GP.

\begin{tabular}{cccccc}
\hline \multirow{2}{*}{ Group } & \multicolumn{4}{c}{ Serum } & \multicolumn{2}{c}{ Liver } \\
\cline { 2 - 6 } & TC $(\mathrm{mg} / \mathrm{dl})$ & TG $(\mathrm{mg} / \mathrm{dl})$ & $\begin{array}{r}\text { HDL-C } \\
(\mathrm{mg} / \mathrm{dl})\end{array}$ & TC $(\mathrm{mg} / \mathrm{dl})$ & TG $(\mathrm{mg} / \mathrm{dl})$ \\
\hline ND (Normal Diet) & $127.9 \pm 23.2$ & $126.4 \pm 51.7$ & $88.7 \pm 27.8$ & $91.4 \pm 34.1$ & $96.5 \pm 28.8$ \\
HFD (High Fat Diet) & $199.9 \pm 37.9^{\mathrm{e}}$ & $66.6 \pm 11.0^{\mathrm{e}}$ & $88.1 \pm 16.1$ & $256.5 \pm 47.4^{\mathrm{e}}$ & $388.4 \pm 92.2^{\mathrm{e}}$ \\
HFD + 0.3\% GP ext. & $207.1 \pm 29.9$ & $82.8 \pm 23.6^{\mathrm{d}}$ & $88.0 \pm 23.6$ & $204.5 \pm 39.7^{\mathrm{f}}$ & $251.9 \pm 106.0^{\mathrm{f}}$ \\
HFD + 1\% GP ext. & $230.4 \pm 33.5$ & $107.3 \pm 83.8^{\mathrm{b}}$ & $87.5 \pm 19.7$ & $189.5 \pm 58.7^{\mathrm{f}}$ & $258.8 \pm 80.2^{\mathrm{f}}$ \\
HFD + 2\% GP seed & $224.7 \pm 39.5$ & $75.3 \pm 15.6$ & $84.6 \pm 7.9$ & $198.0 \pm 85.6^{\mathrm{b}}$ & $236.9 \pm 51.8^{\mathrm{f}}$ \\
\hline
\end{tabular}

All data were expressed as the mean \pm S.D. Differences were examined for statistical significance using Student's t-test. $\mathrm{n}=9$. ${ }^{\mathrm{e}}: p<0.001$ compared with ND values. ${ }^{\mathrm{b}, \mathrm{d} f \mathrm{f}}: p<0.05,0.01,0.001$ compared with HFD values, respectively.
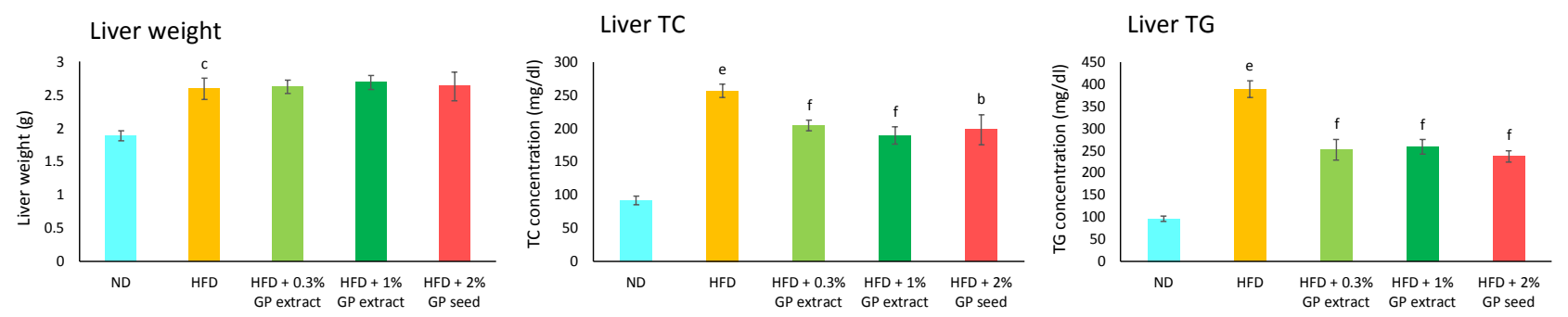

Figure 2. Liver weight, total cholesterol (TC), and triglyceride (TG) concentrations in mice $(\mathrm{n}=9)$ fed a normal diet $(\mathrm{ND})$, high-fat diet (HFD), HFD including $0.3 \%$ GP extract, HFD including $1 \%$ GP extract, and HFD including 2\% GP. (c, e): $p<0.01$, 0.001 compared with ND values respectively. (b, f): $p<0.05,0.001$ compared with HFD values, respectively. 
Serum TC

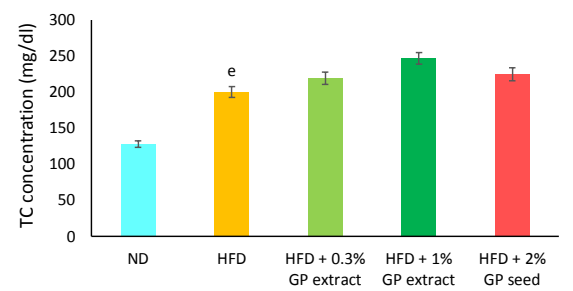

Serum TG

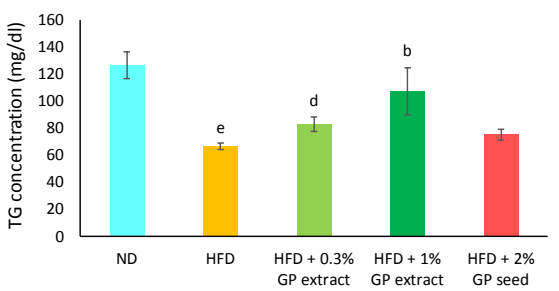

Serum HDL-C

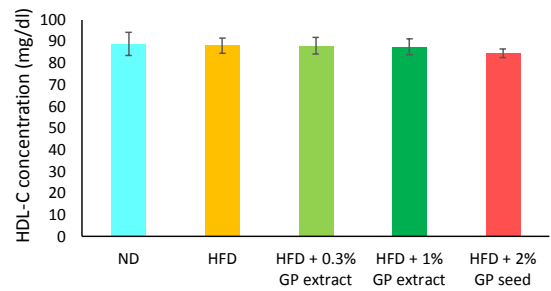

Figure 3. Total cholesterol (TC), triglyceride (TG), and high density lipoprotein-cholesterol (HDL-C) concentrations in serum of mice $(\mathrm{n}=9)$ fed a normal diet (ND), high-fat diet (HFD), HFD including 0.3\% GP extract, HFD including $1 \%$ GP extract, and HFD including $2 \%$ GP. (e): $p<0.001$ compared with ND values. (b, $\mathrm{d}$ ): $p<0.05,0.01$ compared with HFD values, respectively.

\subsection{GP Extract Decreases Brown Adipose Tissue Sympathetic Nerve Activity (BAT SNA)}

To clarify the anti-obesity effect of GP extract in mice, BAT SNA was determined using an electrophysiological method. An initial intragastric infusion of GP extract ( $5 \mathrm{mg} / \mathrm{kg}$ body weight) immediately decreased BAT SNA by around $10 \%$, and this decrease lasted for at least $1 \mathrm{~h}$. After BAT SNA recovery, a second intragastric infusion of GP extract at same concentration produced the same effect on BAT SNA (Figure 4). This procedure was performed on three rats, and produced similar results for each mouse.

\section{Discussion}

The animal breeding experiment in this study was performed to investigate the anti-obesity effects of GP and GP extract. The results are shown in Figures 1-3 and Table $1 \&$ Table 2. The feeding of HFD containing 1\% GP extract for five weeks greatly suppressed body weight gain and fat accumulation in mice. This suggested that GP has the potential to inhibit lipid accumulation. GP intake significantly decreased TC and TG concentrations in liver tissue, and prevented the pale discoloration of the liver, which was observed in the HFD group; however, it had no significant impact on liver weight. The serum TC and HDL-C concentrations in the GP intake groups were unchanged compared with those in the HFD group mice. Serum TG concentrations in the GP intake groups significantly increased. These results suggested that hepatic lipid metabolism was improved by GP intake. Consequently, GP intake potently decreases fat accumulation in HFD mice. De Creamer et al. (1994) reported that hepatomegaly was observed in mice fed a diet rich in fish oil, with no significant changes in body, heart, or kidney weights. They concluded that this could be caused by induction of a liver peroxisome, which regulates $\beta$-oxidation and biosynthesis of bile acid. This metabolic change occurs via peroxisome proliferator-activated receptors (PPAR), which are involved in adipocyte differentiation [20] [21] [22] [23]. One of the components of GP, 6-shogaol, has been proven to activate PPAR [24]. Hence, the unchanged liver weight of mice in the GP groups compared with those of mice in the HFD group observed in this present study might be due to increased PPAR-stimulated hepatic peroxisome induction. 


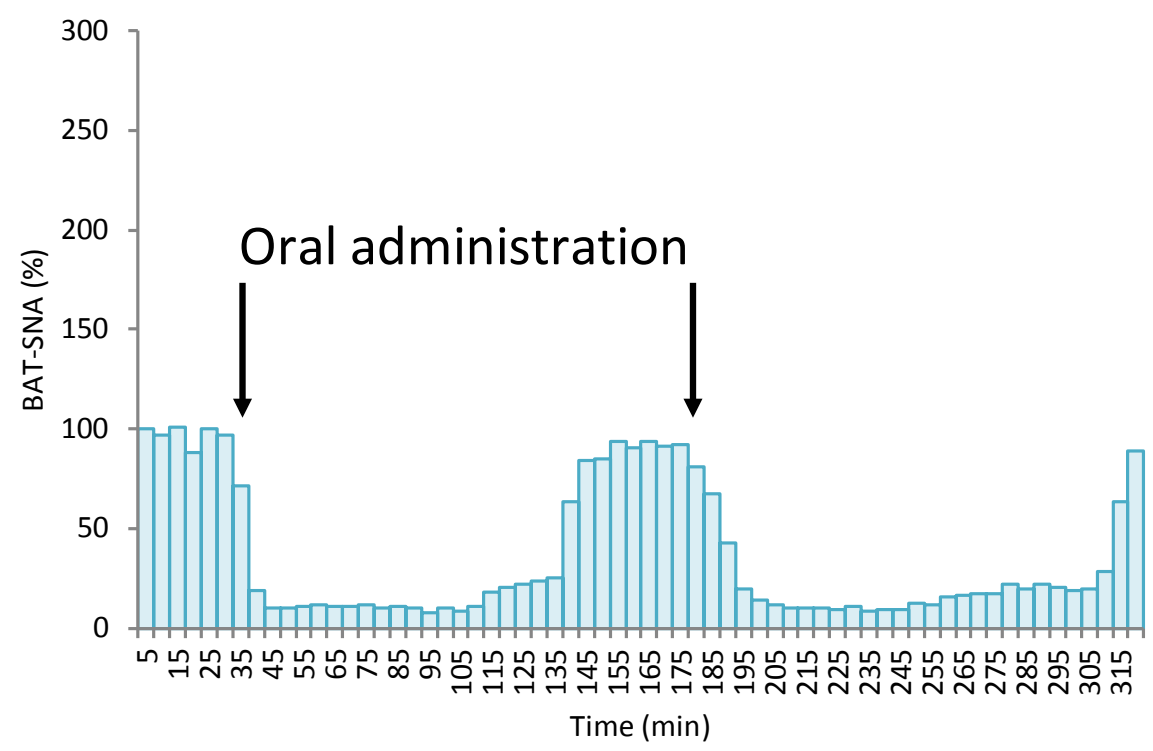

Figure 4. Effect of GP extract on sympathetic nerve activity in the brown adipose tissue. After recording stable sympathetic nerve activity for $30 \mathrm{~min}$, the GP extract of $5 \mathrm{mg} / \mathrm{kg}$ body weight was administered using gastric tube. Similar results were observed from three individuals of rat.

Adipose tissues are classified as either WAT or BAT, which have different functions and morphology [25]. BAT is found in infants, young children, and rodents. Recently, BAT has been observed around the scapula, axilla, and vertebral column of adult humans using ${ }^{18} \mathrm{~F}$-fluorodeoxyglucose $\left({ }^{18} \mathrm{~F}-\mathrm{FDG}\right)$ and positron-emission tomography (PET) [3] [26] [27]. Thermogenesis in BAT is mediated by sympathetic stimulation of BAT mitochondrial uncoupling protein 1 (UCP1). We hypothesized that the anti-obesity activity of GP intake in this mouse breeding test was due to this mechanism, and BAT SNA was involved in the effect of GP extract.

Capsaicin, which is the major ingredient in chili pepper, has the potential to increase energy expenditure and decrease body fat by activating BAT in humans and rodents [28] [29] [30]. This results in stimulation of SNA by transient receptor potential vanilloid 1 (TRPV1), which is expressed in the gastrointestinal tract and sensory nervous system and specifically combines with capsaicin at the vanillyl moiety [15] [31]. The results of the present study were consistent with data obtained from experiments with capsaicin and capsiate, which is also found in chili peppers. Surprisingly however, GP extract exhibits a different mode of action from that of capsaicin and capsiate; GP extract decreases SNA, rather than increasing it as seen with capsaicin and capsiate.

Capsaicin and capsiate bear structural similarities to the non-volatile vanilloids found in GP [32] [33] [34]. It has also been reported that 6-paradol and 6-shogaol in GP extract were found to activate TRPV1 through non-covalent bonding [35]. The HPLC analysis showed that GP extract contains many vanilloid compounds possessing hydrocarbon side chains with a double bond and/or carbonyl group (data not shown). These substructures of vanilloids may be re- 
sponsible for activating BAT SNA. This might suggest that the vanilloids in GP contribute to the anti-obesity effect by stimulating BAT SNA. However, contrary to expectations, BAT SNA was decreased by oral administration of GP extract.

Crocin, ezetimibe, catechins, and caffeine inhibit intestinal absorption of cholesterol and fat by inactivating pancreatic lipase [36] [37] [38]. The aqueous extract of Zingiber officinale Roscoe also prevents intestinal lipid absorption [39] through the actions of vanilloid compounds such as 6-gingerol and 6-shogaol [40]. These reports suggest that GP may inhibit body weight gain in mice by suppressing lipid absorption rather than by activating BAT SNA.

\section{Conclusion}

In summary, the present study demonstrated that GP and its extract exert an anti-obesity effect in HFD-fed mice. Prevention of body weight gain and fat accumulation occurs through improved hepatic lipid metabolism. In addition, BAT SNA decreased with intragastric infusion of GP extract. In general, decreasing BAT SNA would increase parasympathetic nerve activity, thus having a relaxation effect in humans. Therefore, GP or GP extract may have the additional benefit of promoting relaxation while controlling obesity in both humans and animals. Further research is required to clarify the mechanisms of the anti-obesity properties of GP extract; this may require investigation of lipid absorption in the small intestine.

\section{References}

[1] Park, A., Kim, K.W. and Bae, K.-H. (2014) Distinguishing White, Beige and Brown Adipocytes Derived from Mesenchymal Stem Cells. World Journal of Stem Cells, 6 , 33-42. https://doi.org/10.4252/wjsc.v6.i1.33

[2] Joseph, M.R., Jennifer, H.S. and Philipp, E.S. (2015) The Cell Biology of Fat Expression. The Journal of Cell Biology, 208, 501-512. https://doi.org/10.1083/jcb.201409063

[3] Cannon, B. and Nedergaard, J. (2004) Brown Adipose Tissue: Function and Physiological Significance. Physiological Reviews, 84, 277-359.

https://doi.org/10.1152/physrev.00015.2003

[4] Silva, J.E. (2006) Thermogenic Mechanisms and Their Hormonal Regulation. Physiological Reviews, 86, 435-464. https://doi.org/10.1152/physrev.00009.2005

[5] Wijers, S.L., Saris, W.H. and van MarkenLichtenbelt, W.D. (2009) Recent Advances in Adaptive Thermogenesis: Potential Implications for the Treatment of Obesity. Obesity Reviews, 10, 218-226. https://doi.org/10.1111/j.1467-789X.2008.00538.x

[6] Iwu, M.M. (1993) Handbook of African Medicinal Plants. CRC Press Taylor and Francis Group, Boca Raton, FL.

[7] Dokosi, O.B. (1998) Herbs of Ghana. Ghana Universities Press, Accra.

[8] Kenneth, G.N., Olivier, C., Venasius, K.W., Paul, S., Christopher, T.E. and Chen, S. (2014) In Vitro Bactericidal Activity of Diterpenoids Isolated from Aframomum melegueta K. Schum against Strains of Escherichia coli, Listeria monocyto Genes and Staphylococcus aureus. Journal of Ethnopharmacology, 151, 1147-1154.

https://doi.org/10.1016/j.jep.2013.12.035

[9] Ukeh, D.A., Birkett, M.A., Pickett, J.A., Bowman, A.S. and Mordue Luntz, A.J. 
(2009) Repellent Activity of Alligator Pepper, Aframomum melegueta, and Ginger, Zingiber officinale, against the Maize Weevil, Sitophilus zeamais. Phytochemistry, 70, 751-758. https://doi.org/10.1016/j.phytochem.2009.03.012

[10] Onoja, S.O., Omeh, Y.N., Ezeja, M.I. and Chukwu, M.N. (2014) Evaluation of the in Vitro and in Vivo Antioxidant Potentials of Aframomum melegueta Methanolic Seed Extract. Journal of Tropical Medicine, 2014, 1-6. https://doi.org/10.1155/2014/159343

[11] Ilic, N.M., Dey, M., Poulev, A.A., Logendra, S., Kuhn, P.E. and Raskin, I. (2014) Anti-Inflammatory Activity of Grains of Paradise (Aframomum melegueta Schum) Extract. Journal of Agricultural and Food Chemistry, 62, 10452-10457. https://doi.org/10.1021/jf5026086

[12] Mohammed, A., Koorbanally, N.A. and Islam, M.S. (2015) Ethyl Acetate Fraction of Aframomum melegueta Fruit Ameliorates Pancreatic $\beta$-Cell Dysfunction and Major Diabetes-Related Parameters in a Type 2 Diabetes Model of Rats. Journal of Ethnopharmacology, 175, 518-527. https://doi.org/10.1016/j.jep.2015.10.011

[13] El-Halawany, A.M., El Dine, R.S., El Sayed, N.S. and Hattori, M. (2014) Protective Effect of Aframomum melegueta Phenolics against $\mathrm{CCl}_{4}$-Induced Rat Hepatocytes Damage; Role of Apoptosis and Pro-Inflammatory Cytokines Inhibition. Scientific Reports, 4, 5880.

[14] Al Othman, Z.A., Ahmed, Y.B., Habila, M.A. and Ghafar, A.A. (2011) Determination of Capsaicin and Dihydrocapsaicin in Capsicum Fruit Samples Using High Performance Liquid Chromatography. Molecules, 16, 8919-8929. https://doi.org/10.3390/molecules16108919

[15] Saito, M. (2015) Capsaicin and Related Food Ingredients Reducing Body Fat through the Activation of TRP and Brown Fat Thermogenesis. Advances in Food and Nutrition Research, 76, 1-28. https://doi.org/10.1016/bs.afnr.2015.07.002

[16] Pomonis, J.D., Harrison, J.E., Mark, L., Bristol, D.R., Valenzano, K.J. and Walker, K. (2003) N-(4-Tertiarybutylphenyl)-4-(3-Cholorphyridin-2-yl)-Tetrahydropyrazine1(2H)-Carbox-Amide (BCTC), a Novel, Orally Effective Vanilloid Receptor 1 Antagonist with Analgesic Properties: II. in Vivo Characterization in Rat Models of Inflammatory and Neuropathic Pain. Journal of Pharmacology and Experimental Therapeutics, 306, 387-393. https://doi.org/10.1124/jpet.102.046268

[17] Takeuchi, K., Araki, H., Umeda, M., Komoike, Y. and Suzuki, K. (2001) Adaptive Gastric Cytoprotection Is Mediated by Prostaglandin EP1 Receptors: A Study Using Rats and Knockout Mice. Journal of Pharmacology and Experimental Therapeutics, 297, 1160-1165.

[18] Kobayashi, H., Horiguchi-Babamoto, E., Suzuki, M., Makihara, H., Tomozawa, H., Tsubata, M., Shimada, T., Sugiyama, K. and Aburada, M. (2016) Effects of Ethyl Acetate Extract of Kaempferia parviflora on Brown Adipose Tissue. Journal of Natural Medicines, 70, 54-61. https://doi.org/10.1007/s11418-015-0936-2

[19] Iwami, M., Mahmoud, F.A., Shiina, T., Hirayama, H., Shima, T., Sugita, J. and Shimizu, Y. (2011) Extract of Grains of Paradise and Its Active Principle 6-Paradol Trigger Thermogenesis of Brown Adipose Tissue in Rats. Autonomic Neuroscience: Basic and Clinical, 161, 63-67. https://doi.org/10.1016/j.autneu.2010.11.012

[20] De Craemer, D., Vamecq, J., Roels, F., Vallée, L., Pauwels, M. and van den Branden, C. (1994) Peroxisomes in Liver, Heart, and Kidney of Mice Fed a Commercial Fish Oil Preparation: Original Data and Review on Peroxisomal Changes Induced by High-Fat Diets. The Journal of Lipid Research, 35, 1241-1250.

[21] Jennifer, J.S. and John, D.A. (2013) Peroxisome Take Shape. Nature Reviews Molecular Cell Biology, 14, 803-817. https://doi.org/10.1038/nrm3700 
[22] Kersten, S., Desvergne, B. and Wahli, W. (2000) Roles of PPARs in Health and Disease. Nature, 405, 421-424. https://doi.org/10.1038/35013000

[23] Patsouris, D., Reddy, J.K., Müller, M. and Kersten, S. (2006) Peroxisome Proliferator-Activated Receptor $\alpha$ Mediates the Effects of High-Fat Diet on Hepatic Gene Expression. Endocrinology, 147, 1508-1516. https://doi.org/10.1210/en.2005-1132

[24] Isa, Y., Miyakawa, Y., Yanagisawa, M., Goto, T., Kang, M.S., Kawada, T., Morimitsu, Y., Kubota, K. and Tsuda, T. (2008) 6-Shogaol and 6-Gingerol, the Pungent of Ginger, Inhibit TNF- $\alpha$ Mediated Downregulation of Adiponectin Expression via Different Mechanisms in 3T3-L1 Adipocytes. Biochemical and Biophysical Research Communications, 373, 429-434. https://doi.org/10.1016/j.bbrc.2008.06.046

[25] Klaus, S., Ely, M., Encke, D. and Heldmaier, G. (1995) Functional Assessment of White and Brown Adipocyte Development and Energy Metabolism in Cell Culture. Dissociation of Terminal Differentiation and Thermogenesis in Brown Adipocytes. Journal of Cell Science, 108, 3171-3180.

[26] Cypess, A.M., Lehman, S., Williams, G., Tal, I., Rodman, D., Goldfine, A.B., Kuo, F.C., Palmer, E.L., Tseng, Y.H., Doria, A., Kolodny, G.M. and Kahn, C.R. (2009) Identification and Importance of Brown Adipose Tissue in Adult Humans. The New England Journal of Medicine, 360, 1509-1517. https://doi.org/10.1056/nejmoa0810780

[27] Cinti, S. (2005) The Adipose Organ. Prostaglandins Leukotrienes Essential Fatty Acids, 73, 9-15. https://doi.org/10.1016/j.plefa.2005.04.010

[28] Kawada, T., Hagihara, K. and Iwai, K. (1986) Effects of Capsaicin on Lipid Metabolism in Rats Fed a High Fat Diet. The Journal of Nutrition, 116, 1272-1278.

[29] Ludy, M.J., Moore, G.E. and Mattes, R.D. (2012) The Effects of Capsaicin and Capsiate on Energy Balance: Critical Review and Meta-Analyses of Studies in Humans. Chemical Senses, 37, 103-121. https://doi.org/10.1093/chemse/bjr100

[30] Holzer, P. (1991) Capsaicin: Cellular Targets, Mechanisms of Action, and Selectivity for Thin Sensory Neurons. Pharmacological Reviews, 43, 143-201.

[31] Saito, M. and Yoneshiro, T. (2013) Capsinoids and Related Food Ingredients Activating Brown Fat Thermogenesis and Reducing Body Fat in Humans. Current Opinion in Lipidology, 24, 71-77. https://doi.org/10.1097/MOL.0b013e32835a4f40

[32] El-Halawany, A.M. and Hattori, M. (2012) Anti-Estrogenic Diarylheptanoids from Aframomum melegueta with in Silico Estrogen Receptor Alpha Binding Conformation Similar to Enterodiol and Enterolactone. Food Chemistry, 134, 219-226. https://doi.org/10.1016/j.foodchem.2012.02.100

[33] Calixto, J.B., Kassuya, C.A., Andre, E. and Ferreira, J. (2005) Contribution of Natural Products to the Discovery of the Transient Receptor Potential (TRP) Channels Family and Their Functions. Pharmacology and Therapeutics, 106, 179-208. https://doi.org/10.1016/j.pharmthera.2004.11.008

[34] Tackie, A.N., Dwuma-Badu, D., Ayim, J.S.K., Dabra, T.T., Knapp, J.E., Slatkin, D.J. and Schiff, P.L.J. (1975) Hydroxyphenylalkanones from Amomum melegueta. Phytochemistry, 14, 853-854. https://doi.org/10.1016/0031-9422(75)83070-6

[35] Riera, C.E., Menozzi-Smarrito, C., Affolter, M., Michlig, S., Munari, C., Robert, F., Vogel, H., Simon, S.A. and le Coutre, J. (2009) Compounds from Sichuan and Melegueta Peppers Activate, Covalently and Non-Covalently, TRPA1 and TRPV1 Channels. British Journal of Pharmacology, 157, 1398-1409. https://doi.org/10.1111/j.1476-5381.2009.00307.x

[36] Sheng, L., Qian, Z., Zheng, S. and Xi, L. (2006) Mechanism of Hypolipidemic Effect of Crocin in Rats: Crocin Inhibits Pancreatic Lipase. European Journal of Pharma- 
cology, 543, 116-122. https://doi.org/10.1016/j.ejphar.2006.05.038

[37] Brown, W.V. (2003) Cholesterol Absorption Inhibitors: Defining New Options in Lipid Management. Clinical Cardiology, 26, 259-264.

https://doi.org/10.1002/clc.4950260604

[38] Wang, S., Noh, S.K. and Koo, S.I. (2006) Epigallocatechin Gallate and Caffeine Differentially Inhibit the Intestinal Absorption of Cholesterol and Fat in Ovariectomized Rats. Journal of Nutrition, 136, 2791-2796.

[39] Han, L.K., Gong, X.J., Kawano, S., Saito, M., Kimura, Y. and Okuda, H. (2005) Antiobesity Actions of Zingiber officinale Roscoe. Yakugaku Zasshi, 125, 213-217. https://doi.org/10.1248/yakushi.125.213

[40] Saravanan, G., Ponmurugan, P., Deepa, M.A. and Senthilkumar, B. (2014) Anti-Obesity Action of Gingerol: Effect on Lipid Profile, Insulin, Leptin, Amylase and Lipase in Male Obese Rats Induced by a High-Fat Diet. Journal of the Science of Food and Agriculture, 94, 2972-2977. https://doi.org/10.1002/jsfa.6642

Submit or recommend next manuscript to SCIRP and we will provide best service for you:

Accepting pre-submission inquiries through Email, Facebook, LinkedIn, Twitter, etc. A wide selection of journals (inclusive of 9 subjects, more than 200 journals)

Providing 24-hour high-quality service

User-friendly online submission system

Fair and swift peer-review system

Efficient typesetting and proofreading procedure

Display of the result of downloads and visits, as well as the number of cited articles

Maximum dissemination of your research work

Submit your manuscript at: http://papersubmission.scirp.org/

Or contact ajps@scirp.org 